\title{
Association of cellular and molecular responses in the rat mammary gland to $17 \beta$-estradiol with susceptibility to mammary cancer
}

Lina Ding ${ }^{1,3}$, Yang Zhao ${ }^{3}$, Christopher L Warren ${ }^{1}$, Ruth Sullivan ${ }^{2,4,5}$, Kevin W Eliceiri ${ }^{2,5}$ and James D Shull ${ }^{1,2,3^{*}}$

\begin{abstract}
Background: We are using $\mathrm{ACl}$ and $\mathrm{BN}$ rats, which differ markedly in their susceptibility to $17 \beta$-estradiol (E2)-induced mammary cancer, to identify genetic variants and environmental factors that determine mammary cancer susceptibility. The objective of this study was to characterize the cellular and molecular responses to E2 in the mammary glands of $\mathrm{ACl}$ and $\mathrm{BN}$ rats to identify qualitative and quantitative phenotypes that associate with and/or may confer differences in susceptibility to mammary cancer.
\end{abstract}

Methods: Female ACl and BN rats were treated with E2 for 1, 3 or 12 weeks. Mammary gland morphology and histology were examined by whole mount and hematoxylin and eosin (H\&E) staining. Cell proliferation and epithelial density were evaluated by quantitative immunohistochemistry. Apoptosis was evaluated by quantitative western blotting and flow cytometry. Mammary gland differentiation was examined by immunohistochemistry. Gene expression was evaluated by microarray, qRT-PCR and quantitative western blotting assays. Extracellular matrix (ECM) associated collagen was evaluated by Picrosirius Red staining and Second Harmonic Generation (SHG) microscopy.

Results: The luminal epithelium of $\mathrm{ACl}$ rats exhibited a rapid and sustained proliferative response to E2. By contrast, the proliferative response exhibited by the mammary epithelium of BN rats was restrained and transitory. Moreover, the epithelium of BN rats appeared to undergo differentiation in response to E2, as evidenced by production of milk proteins as well as luminal ectasia and associated changes in the ECM. Marked differences in expression of genes that encode proteins with well-defined roles in mammary gland development (Pgr, Wnt4, Tnfsf11, Prlr, Stat5a, Areg, Gata3), differentiation and milk production (LCn2, Spp1), regulation of extracellular environment (Mmp7, Mmp9), and cell-cell or cell-ECM interactions (Cd44, Cd24, Cd52) were observed.

Conclusions: We propose that these cellular and molecular phenotypes are heritable and may underlie, at least in part, the differences in mammary cancer susceptibility exhibited by $\mathrm{ACl}$ and $\mathrm{BN}$ rats.

Keywords: ACI rat, BN rat, Breast cancer susceptibility, Cell proliferation, Gene expression, Epithelial density

\footnotetext{
*Correspondence: shull@oncology.wisc.edu

'McArdle Laboratory for Cancer Research, Department of Oncology, School

of Medicine and Public Health, University of Wisconsin Madison, 1400 University Avenue, Madison, WI 53706, USA

UW Carbone Cancer Center, University of Wisconsin Madison, School of

Medicine and Public Health, University of Wisconsin Madison, 600 Highland

Avenue, Madison, WI 53792, USA

Full list of author information is available at the end of the article
}

\section{Biomed Central}

(c) 2013 Ding et al.; licensee BioMed Central Ltd. This is an open access article distributed under the terms of the Creative Commons Attribution License (http://creativecommons.org/licenses/by/2.0), which permits unrestricted use, distribution, and reproduction in any medium, provided the original work is properly cited. 


\section{Background}

In spite of recent advances in diagnosis and treatment, breast cancer remains the second leading cause of cancer-related death in women in the United States. The existence of multiple subtypes of breast cancer, each with unique clinical and/or molecular characteristics, is now well established [1,2]. Multiple genetic and environmental factors contribute to breast cancer development, and it is becoming increasingly clear that development of each breast cancer subtype is influenced by different sets of factors. Known risk factors include a family history of breast cancer, cumulative exposure to endogenous and exogenous estrogens and breast mammographic density [3-9]. Although several genes have been identified that significantly impact breast cancer risk when mutated or aberrantly expressed, only a small fraction of the overall population risk can be attributed to these genes [10-12]. Similarly, the genetic determinants of responsiveness to estrogens and mammographic density remain poorly defined.

We are using inbred ACI (August x Copenhagen, Irish), $\mathrm{COP}$ (Copenhagen) and $\mathrm{BN}$ (Brown Norway) rats to define the mechanisms through which estrogens contribute to mammary cancer development and identify genetic determinants of susceptibility to mammary cancer. When treated continuously with $17 \beta$-estradiol (E2), female ACI rats develop mammary carcinoma at an incidence approaching 100\% [13]. The mammary cancers that develop in E2 treated ACI rats express estrogen receptor- $\alpha$ (ER $\alpha)$ and progesterone receptor (Pgr), are dependent upon E2 for continued growth and survival, and frequently exhibit chromosome copy number changes and instability [14-16]. Development of mammary cancer in E2 treated ACI rats is dramatically inhibited by concurrent treatment with tamoxifen, indicating a requirement for one or more estrogen receptor mediated mechanisms in tumor development $[17,18]$. Interestingly, tumor development in ACI rats also requires the action of progesterone [13,19]. By contrast, $\mathrm{COP}$ and $\mathrm{BN}$ rats are resistant to E2-induced mammary cancer [20-22]. Multiple genetic determinants of susceptibility to E2-induced mammary cancer, designated Emca1 (Estrogen-induced mammary cancer 1) through Emca9, have been mapped in crosses between susceptible ACI rats and resistant $\mathrm{COP}$ or $\mathrm{BN}$ rats [21-24]. Each of the mapped quantitative trait loci (QTL) encompass segments of the rat genome that are orthologous to regions of the human genome linked to breast cancer risk in genome wide association studies (GWAS). Together, these data indicate that the ACI rat model of E2-induced mammary cancer is a physiologically relevant model for studying the molecular etiology of luminal type breast cancers.

The purpose of this study was to define, both qualitatively and quantitatively, the manner in which the mammary glands of susceptible $\mathrm{ACI}$ and resistant $\mathrm{BN}$ rats respond to E2. Dramatic differences in multiple cellular and molecular responses to E2 were observed when these two inbred rat strains were compared. These differences contributed to and/or were associated with differences in epithelial density, mammary gland differentiation and ECM, as well as differential expression of many genes of known significance to mammary gland development. We propose that the observed differences in responsiveness of the mammary gland to E2 represent phenotypes that underlie the documented strain differences in susceptibility to mammary cancer and may also contribute to and/ or serve as biomarkers of breast cancer risk in humans.

\section{Methods}

\section{Care and treatment of animals}

All procedures involving live animals were approved by the Animal Care and Use Committee of the University of Wisconsin-Madison. Female $\mathrm{ACI}$ and $\mathrm{BN}$ rats were purchased from Harlan Laboratories (Indianapolis, IN). As described previously, Silastic ${ }^{\mathrm{TM}}$ tubing implants (Dow Corning, Midland, MI), empty or containing $27.5 \mathrm{mg}$ of E2 (Sigma-Aldrich, St. Louis, MO), were made and placed surgically into the interscapular region of 9 week old rats; these implants release hormone continuously and maintain circulating E2 at levels normally observed in pregnant rats $[13,25]$. Groups of sham treated (empty implant) control and E2 treated rats were euthanized 1, 3 or 12 weeks later. Each rat was injected with 5-bromo-2'-deoxyuridine (BrdU, Sigma-Aldrich), administered intraperitoneally in phosphate buffered saline (PBS) at $50 \mathrm{mg} / \mathrm{kg}$ body weight, four hours before termination of the experiments. Mammary tissues were collected and processed as described below to quantify various cellular and molecular phenotypes.

\section{Evaluation of mammary gland morphology and histology}

Mammary gland whole mounts were generated to evaluate gland morphology. The left inguinal and abdominal mammary glands were collected, stretched flat onto Apex Superior Adhesive Slides (Leica Biosystems, Buffalo Grove, IL), and fixed in 25\% glacial acetic acid in ethanol overnight at room temperature. The glands were stained overnight at room temperature in $2 \mathrm{mg} / \mathrm{ml}$ carmine (Sigma-Aldrich) and dehydrated in 70\%, 95\% and 100\% ethanol [26]. Finally, the glands were cleared by submersion in xylene, approximately $100 \mathrm{ml}$ per slide, which was changed daily until the epithelial structures could be clearly observed. The whole mounts were photographed using an SZX9 dissecting microscope equipped with a C-7070 digital camera (Olympus, Center Valley, PA).

To evaluate mammary gland histology, the glands were collected and fixed overnight at room temperature in 4\% paraformaldehyde. The fixed tissues were then transferred to $70 \%$ ethanol, processed and embedded in paraffin. Sections (5.0 microns) were cut, mounted on slides, stained 
with H\&E and evaluated by bright field microscopy. Photomicrographs were obtained using a Zeiss Axio Imager.M2 microscope equipped with an AxioCam HRc digital camera (Carl Zeiss, Thornwood, NY).

\section{Quantitative immunohistochemistry (IHC)}

Paraffin embedded mammary tissues were cut to $5.0 \mathrm{mi}-$ crons, mounted on slides, deparaffinized in xylene and rehydrated stepwise in ethanol at decreasing concentration (100\% (twice), 95\%, 90\%, 80\%, 70\%, 50\%). The tissues were permeabilized in $0.5 \%$ Triton X-100 in PBS and antigens were retrieved by boiling in $0.01 \mathrm{M}$ sodium citrate $(\mathrm{pH} 6.0)$ for 10 minutes. The sections were then incubated in 10\% goat serum (diluted in PBS) for $1 \mathrm{~h}$ at room temperature; incubated overnight at $4^{\circ} \mathrm{C}$ in a primary antibody, diluted as described in Additional file 1: Table S1; rinsed three times for 5 minutes each with $0.1 \%$ Tween-20 in PBS (0.1\% PBST); incubated with the appropriate secondary antibody (Additional file 1: Table S1) for 1 hour at room temperature; rinsed three times for 5 minutes each in $0.1 \%$ PBST; and incubated in Prolong Gold Anti-Fade plus 4',6-diamidino-2-phenylindole (DAPI, Life Technologies, Carlsbad CA). The stained sections were visualized by fluorescence microscopy using an Axio Imager.M2 microscope equipped with an Apotome structured illumination imaging system and an AxioCam MRm digital camera (Carl Zeiss).

Quantitative IHC was performed using a Vectra ${ }^{\text {Tw }}$ multispectral fluorescence imaging system running Nuance 3.0.0 imaging software (Caliper Life Sciences, Hopkinton, MA). High-resolution (1,360 × 1,024 pixel), 8-bit grayscale images were acquired automatically every fourth field over the entire tissue section. The nuclear compartment was defined by DAPI (blue). Cytokeratin 5 (K5) and cytokeratin 8 (K8) were visualized using secondary antibodies conjugated with Alexa Fluor 488 (green) and Alexa Fluor 546 (red), respectively. Cells that incorporated BrdU during the $\mathrm{S}$ phase of the cell cycle were visualized using a secondary antibody conjugated with Alexa Fluor 647 (yellow). An unstained section of mammary tissue was used to build a spectral library for autofluorescence. Sections stained with a single chromogen were used to build spectral libraries for DAPI, Alexa Fluor 488, Alexa Fluor 546 and Alexa Fluor 647. These libraries allowed the different fluorophores to be distinguished from one other and from autofluorescence without spectral overlap. The inform 1.2 analysis software (Caliper Life Sciences) was trained to distinguish epithelium from non-epithelium and to define subcellular compartments (nucleus, cytoplasm and membrane) and was subsequently used to quantify the fraction of luminal epithelial cells in the $\mathrm{S}$ phase of the cell cycle (K8/BrdU double positive) as well as the number of luminal epithelial cells (DAPI/K8 double positive) per field.

\section{Quantification of apoptosis}

Freshly isolated inguinal and abdominal mammary glands were cut into small segments and digested for 6 hours at $37^{\circ} \mathrm{C}$ in Dulbecco's modified Eagle's medium/F12 (DMEM/ F12, Life Technologies) supplemented with $5 \%$ fetal bovine serum (FBS, Life Technologies), $300 \mathrm{U} / \mathrm{ml}$ collagenase (STEMCELL Technologies, Vancouver, BC) and $100 \mathrm{U} / \mathrm{ml}$ hyaluronidase (STEMCELL Technologies). The resulting organoids were reduced to single cells by digestion with $0.25 \%$ Trypsin (STEMCELL Technologies), 5mg/ $\mathrm{ml}$ Dispase (STEMCELL Technologies) and 5,000 U/ml DNase I (Roche Applied Science, Indianapolis, IN). The dissociated cells were filtered through $25 \mu \mathrm{m}$ cell strainers and were stained with Alexa Fluor 647 labeled Annexin V conjugate (Life Technologies) and propidium iodide (PI, Sigma-Aldrich) [27]. The stained cells were analyzed using a FACSCalibur flow cytometer running CellQuestPro version 5.2.1 data acquisition software (BD Biosciences, San Jose, CA). Subsequent data analyses were performed using FlowJo version 9.6 (TreeStar Inc., Ashland, OR).

\section{Evaluation of gene expression}

Gene expression profiles were defined for $\mathrm{ACI}$ and $\mathrm{BN}$ rats that had been treated with E2 for 12 weeks ( $n=5$ rats per group) using Affymetrix Rat Genome 2302.0 GeneChips Arrays (Affymetrix, Santa Clara, CA) as described previously [24]. The primary microarray data have been deposited in Gene Expression Omnibus under accession number GSE49548. Gene ontology enrichment analyses were performed using Ontologizer 2.0 as described previously [24].

Differential expression of selected genes was further evaluated by quantitative real-time PCR (qRT-PCR). Total RNA was isolated from frozen mammary tissue using an Aurum Total RNA Fatty and Fibrous Tissue Kit (Bio-Rad, Hercules, CA). Single-stranded cDNA was synthesized using $1 \mu \mathrm{g}$ RNA and an iScript cDNA Synthesis Kit (Bio-Rad). qRT-PCR was performed using TaqMan Gene Expression Master Mix (Life Technologies), a CFX96 multicolor real-time PCR detection system (Bio-Rad) and pre-designed TaqMan primers and probes (Integrated DNA Technologies, Coralville, IA): Pgr (Rn.PT.53.36352803), Wnt4 (Rn.PT.53.34796012), Tnfsf11 (Rn.PT.53.13125438), Spp1 (Rn.PT.51.10587746. g), Lcn2 (Rn.PT.51.11294783), Mmp7 (Rn.PT.51.1049 9639), Mmp9 (Rn.PT.53a.7321135), Lef1 (Rn.PT.51.535 4713) and $A c t b$ (Rn.PT.51.13516462). The PCR program was $95^{\circ} \mathrm{C}$ for 10 minutes followed by 40 cycles at $95^{\circ} \mathrm{C}$ for 10 seconds and $60^{\circ} \mathrm{C}$ for 45 seconds. The data for each gene were analyzed using the $\Delta \Delta \mathrm{Cq}$ method and CFX Manager Software version 2.1 (Bio-Rad) and are illustrated relative to expression levels of Actb. 


\section{Quantitative western blotting}

Frozen mammary tissues were homogenized with PowerGen Model 35 Handheld Homogenizer (Thermo Fisher Scientific, Waltham, MA) in lysis buffer containing $25 \mathrm{mM}$ HEPES (pH 7.4), $300 \mathrm{mM} \mathrm{NaCl}, 1.5 \mathrm{mM}$ $\mathrm{MgCl}_{2}, 1 \mathrm{mM}$ EGTA, $0.2 \mathrm{mM} \mathrm{Na} \mathrm{VO}_{4}, 50 \mathrm{mM}$ glycerophosphate, $0.5 \%$ Triton X-100 and 1\% Halt Proteinase and Phosphatase Inhibitor Cocktail (Thermo Fisher Scientific). The lysates were centrifuged at $12,000 \mathrm{~g}$ for $30 \mathrm{~min}$, the supernatants were collected and protein concentration was determined using BCA Protein Assay Reagent (Thermo Fisher). Spp1 and Lcn2 were quantified using the Odyssey Imaging System (LI-COR, Lincoln, NE). Briefly, mammary proteins were separated by SDSPAGE and transferred to Immobilon-FL PVDF membranes (Millipore, Billerica, MA). The blots were incubated with Odyssey blocking buffer (LI-COR) for $1 \mathrm{~h}$ at room temperature; incubated overnight at $4^{\circ} \mathrm{C}$ with primary antibody diluted in Odyssey blocking buffer containing $0.1 \%$ Tween-20 as described in Additional file 1: Table S1; washed four times for 5 minutes each with $0.1 \%$ PBST; incubated with the appropriate IRDye-conjugated secondary antibody (Additional file 1: Table S1) for $1 \mathrm{~h}$ at room temperature in the dark; washed four times for 5 minutes each with $0.1 \%$ PBST; imaged and quantified. Cleaved caspase 3, Mmp7 and Mmp9 were quantified using the ChemiDoc XRS + imaging system (Bio-Rad). SDS-PAGE and protein transfer were performed as described above. The blots were then incubated in PBS containing $5 \%$ non-fat milk and $0.1 \%$ Tween-20 for 1 hour at room temperature; incubated overnight at $4{ }^{\circ} \mathrm{C}$ in the same buffer containing primary antibody as indicated in Additional file 1: Table S1; washed four times for 5 minutes each with $0.1 \%$ PBST; incubated in horseradish peroxidase conjugated secondary antibody for 1 $\mathrm{h}$ at room temperature (Additional file 1: Table S1); and washed four times for 5 minutes each with $0.1 \%$ PBST. The proteins were visualized using SuperSignal West Dura Chemiluminescent Substrate (Thermo Fisher), imaged and quantified using Image Lab 4.0.1 software (Bio-Rad). All blots were also probed with an antibody to $\beta$-actin (Additional file 1: Table S1) and expression of each protein of interest was normalized relative to the amount of $\beta$-actin.

\section{Evaluation of extracellular matrix collagen}

Paraffin embedded mammary tissues were sectioned, deparaffinized, rehydrated and stained with Picrosirius Red (Sigma-Aldrich) to visualize ECM collagen; counter stained with Fast Green FCF (Sigma-Aldrich) to visualize non-collagenous cellular and matrix constituents; imaged and photographed using a BX60 epifluroescence microscope equipped with a DP25 digital camera and cellSens digital imaging software (Olympus). Halogen bulb based illumination was used for polarized light and brightfield microscopy. SHG for visualization of collagen was conducted on a custom multiphoton laser scanning microscope $[28,29]$. All SHG images were collected at a wavelength of $890 \mathrm{~nm}$ with a $445 \mathrm{~nm}$ (20 nm bandpass) filter (Semrock, Rochester, NY).

\section{Statistical analysis of data}

Differences between groups were evaluated using Student's two-tailed t-test. Significance was established at $p<0.05$.

\section{Results}

Rat strain specific effects of $17 \beta$-estradiol on mammary gland morphology and histology

Mammary gland morphology and histology were evaluated at 1,3 and 12 weeks relative to the initiation of treatment at 9 weeks of age to determine whether or not the mammary glands of susceptible ACI rats and resistant $\mathrm{BN}$ rats differ in their responsiveness to E2. Figure 1A illustrates a typical whole mount of the left abdominal and inguinal mammary glands from a 10 weeks old, ovary intact, ACI rat. Figure 1B represents higher magnification images of the region of the abdominal mammary gland of sham or E2 treated $\mathrm{ACI}$ or $\mathrm{BN}$ rats represented by the rectangle in Figure 1A. The mammary glands of sham treated $\mathrm{ACI}$ and $\mathrm{BN}$ rats were comprised of elongated, branched ductal structures that extended to the margins of the mammary fat pad and terminated in small clusters of epithelial cells. No discernible differences in mammary gland morphology were observed between sham treated $\mathrm{ACI}$ rats and BN rats. E2 treatment induced a marked increase in the size and complexity of the epithelial structures in the mammary glands of $\mathrm{ACI}$ rats. This response was observed within 1 week of initiation of E2 treatment and remained apparent following 3 and 12 weeks of treatment. By contrast, the impact of E2 treatment on the size and complexity of the epithelial structures in $\mathrm{BN}$ rats was modest (Figure 1B).

Examination of H\&E stained sections demonstrated that the mammary glands of sham treated $\mathrm{ACI}$ and $\mathrm{BN}$ rats consisted of ducts, terminal duct lobule units and associated ECM embedded within the mammary fat pad (Figure 1C). No discernible differences in mammary gland histology were observed between sham treated ACI and $\mathrm{BN}$ rats at any of the three time points. The mammary glands of E2 treated ACI rats consisted of large clusters of epithelial cells organized around the mammary ducts, consistent with induction of lobuloalveolar hyperplasia. This hyperplastic response to E2 was apparent within 1 week of initiation of treatment and appeared similar following 3 and 12 weeks of treatment. Although E2 treatment led to an increase in the apparent size of the epithelial structures in the mammary glands of $\mathrm{BN}$ rats, this resulted primarily from 


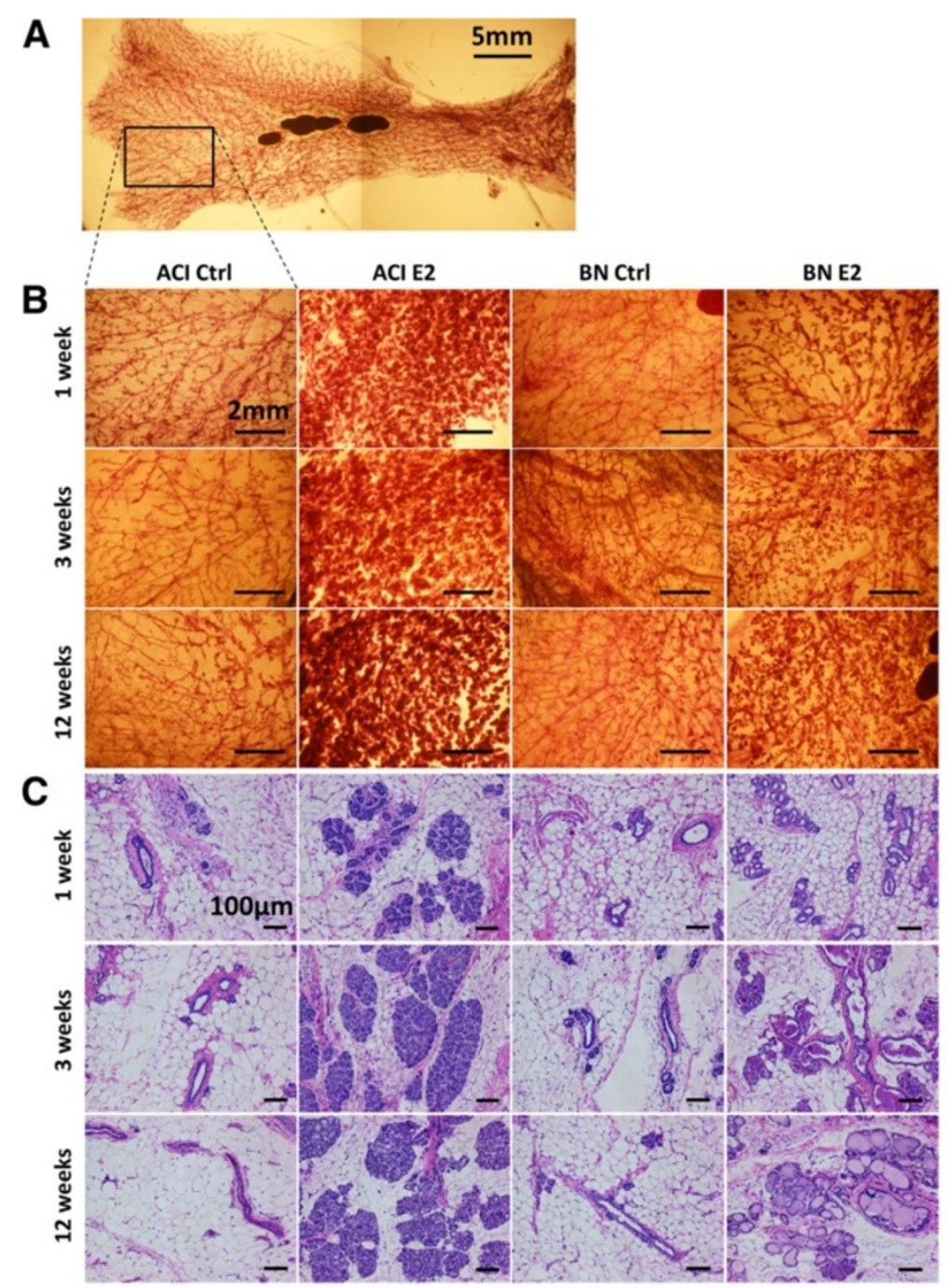

Figure 1 Rat strain-specific effects of $17 \beta$-estradiol on mammary gland morphology and histology. A, Representative whole mount of abdominal/inguinal mammary glands from a 10 weeks old ACl female. Left, anterior. Right, posterior. Up, medial. Down, lateral. The rectangle illustrates the approximate region of the abdominal gland illustrated in Panels $\mathbf{B}$. Scale bar, $5 \mathrm{~mm}$. B, Representative images of mammary gland whole mounts from $\mathrm{ACl}$ and $\mathrm{BN}$ rats, either sham treated (Ctrl) or treated with E2 for 1,3 or 12 weeks $(n=3)$. Scale bars, $2 \mathrm{~mm}$. $\mathbf{C}$, Representative images of mammary tissues, sectioned and stained with hematoxylin and eosin, from ACl and BN rats treated as described in Panels $\mathbf{B}(n \geq 5)$. Scale bars, $100 \mu \mathrm{m}$.

luminal ectasia in addition to a slight but discernible induction of lobuloalveolar hyperplasia. The luminal ectasia was apparent within 1 week of initiation of E2 treatment and remained the predominant feature in the mammary glands of E2 treated BN rats following 3 and 12 weeks of treatment. Together, these data illustrate remarkable differences in the cellular responses to E2 within the mammary glands of $\mathrm{ACI}$ and $\mathrm{BN}$ rats that are discernible within 1 week of initiation of hormone treatment.

\section{Rat strain specific effects of $17 \beta$-estradiol on mammary} cell proliferation and differentiation, but not apoptosis Proliferation in defined mammary cell populations was quantified by IHC using antibodies to $\mathrm{K} 5$, a marker of basal epithelium, K8, a marker of luminal epithelium, and BrdU, a marker for cells that transited the $\mathrm{S}$ phase of the cell cycle within the 4 hours preceding euthanasia. Representative images from $\mathrm{ACI}$ and $\mathrm{BN}$ rats treated for 1 week with E2 and age matched, sham treated, control rats are illustrated in Figure 2A. Images generated at the 3 week and 12 week time points are appended as Additional file 2: Figure S1A and S1B, respectively. The mammary epithelia of both control and E2 treated ACI and $\mathrm{BN}$ rats were comprised of an outer layer of basal cells surrounding the inner luminal cells. Quantification by Vectra system demonstrated that the fraction of BrdU positive cells in the luminal epithelium of sham treated $\mathrm{ACI}$ and $\mathrm{BN}$ rats was below $1.0 \%$ at each of the time 


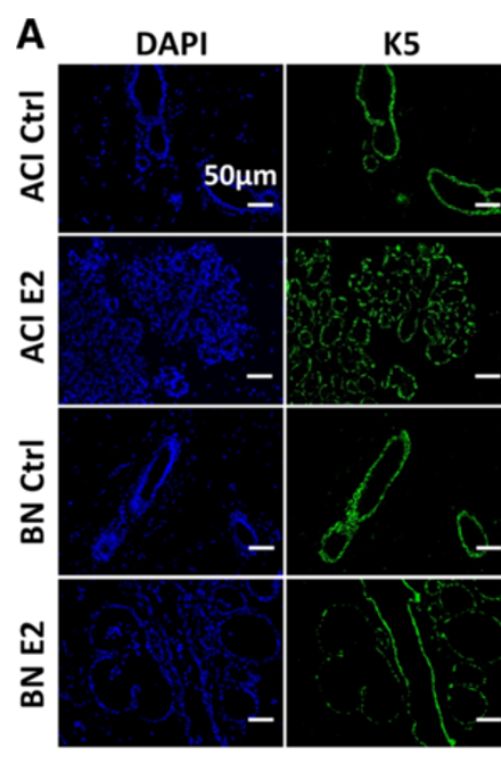

B

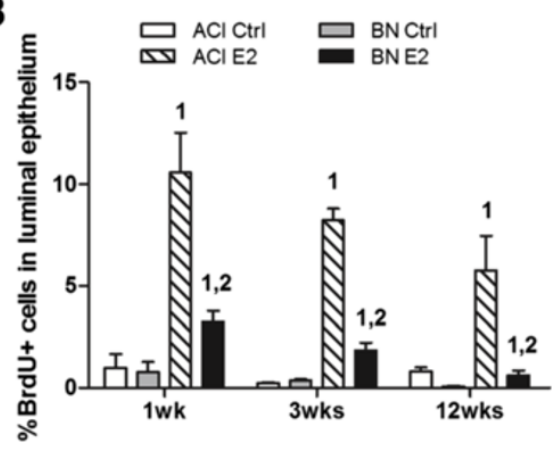

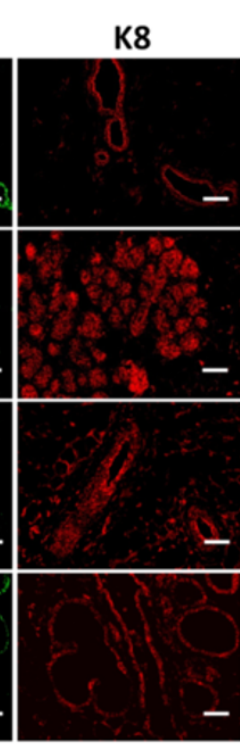
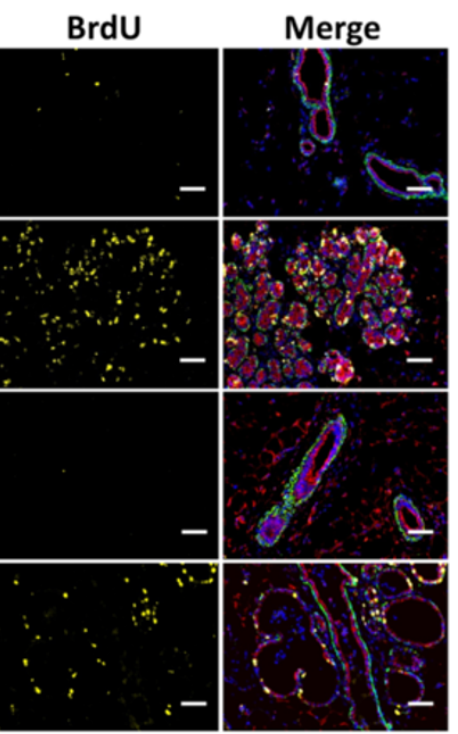

C

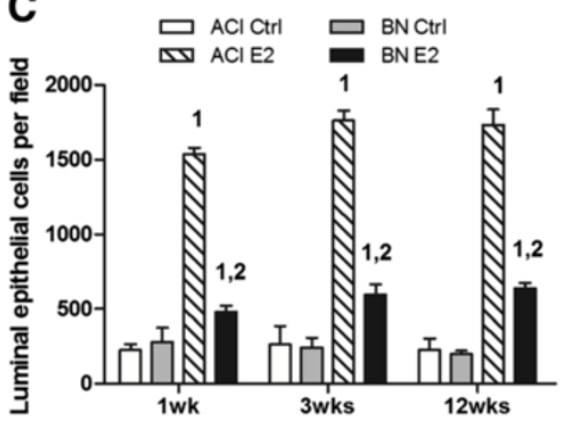

Figure 2 Rat strain-specific effects of $17 \beta$-estradiol on mammary epithelial cell proliferation. A, Representative fluorescent images of mammary tissues from $\mathrm{ACl}$ and $\mathrm{BN}$ rats, either sham treated $(\mathrm{Ctrl})$ or treated with $\mathrm{E} 2$ for 1 week $(\mathrm{n}=3)$. Column 1 , nuclei identified by staining DNA with 4',6-diamidino-2-phenylindole (DAPI, blue). Column 2, basal epithelial cells were identified by immunostaining for cytokeratin 5 (K5, green). Column 3, luminal epithelial cells were identified by immunostaining for cytokeratin 8 (K8, red). Colum 4, cells transiting $\mathbf{S}$ phase were identified by immunostaining for BrdU (yellow). Column 5, merged images from columns 1 through 4. Scale bars, $50 \mu$ m. B, The number of luminal epithelial cells (K8 positive) in S phase (BrdU positive) was quantified using a Vectra ${ }^{\mathrm{TM}}$ multispectral fluorescence imaging system and illustrated as the percentage of total luminal epithelial cells. C, The number of luminal epithelial cells per field was quantified as an indicator of epithelial density. Each data bar in Panels B and C represents the mean \pm standard error of the mean $(\mathrm{SEM}, \mathrm{n}=3) .1, p<0.05$ for comparison of E2 treated vs. sham treated rats of same strain. $2, p<0.05$ for comparison of $E 2$ treated $B N$ vs. treated $A C l$ rats.

points and did not differ between strains (Figure 2A and 2B). Treatment with E2 dramatically induced proliferation within the luminal epithelium of ACI rats. The fraction of luminal cells staining positive for BrdU was increased to $10.6 \%, 8.2 \%$ and $5.8 \%$ in ACI rats treated with E2 for 1,3 and 12 weeks, respectively. By contrast, E2 treatment increased the fraction of luminal cells staining positive for BrdU in BN rats to only $3.2 \%$ following 1 week and $1.8 \%$ following 3 weeks of treatment, and no significant increase was observed in $\mathrm{BN}$ rats treated with $\mathrm{E} 2$ for 12 weeks (Figure 2A and 2B). The fraction of $\mathrm{S}$ phase cells in the luminal epithelium of E2 treated ACI rats was significantly greater than in treated $\mathrm{BN}$ rats at each of the three time points. The difference in induction of luminal epithelial cell proliferation in these two rat strains was clearly reflected in the morphological and histological differences described above (Figure 1B, 1C and 2A), as well as in differences in epithelial density measured by quantifying the number of luminal epithelial cells per microscopic field. This indicator of epithelial density did not differ between sham treated $\mathrm{ACI}$ and $\mathrm{BN}$ rats at any of the time points examined (Figure 2C). The number of luminal epithelial cells per field was increased more than 6-fold in ACI rats treated with E2 for 1, 3 or 12 weeks, relative to age-matched control ACI rats. By contrast, the number of luminal epithelial cells per field was increased 1.7-, 2.4and 3.2-fold in BN rats treated for 1, 3 and 12 weeks, respectively, relative to control $\mathrm{BN}$ rats. Together, these data demonstrate that the proliferative response of the luminal epithelium of ACI rats to E2 is markedly greater 
than that of $\mathrm{BN}$ rats. Proliferation in the basal epithelium was not quantified because the basal cells in E2 treated rats assumed an elongated morphology that made it difficult to assign a specific nucleus to the cells staining positive for K5.

Apoptosis within the mammary gland was evaluated using two independent methods. In the first, the levels of the activated 17 and $19 \mathrm{kDa}$ forms of caspase 3 were quantified by western blotting. No significant differences in the levels of cleaved caspase 3 were observed when mammary glands from E2 treated ACI and BN rats were compared (Figure $3 \mathrm{~A}$ and $3 \mathrm{~B}$ ). Binding of Annexin $\mathrm{V}$ to dispersed mammary cells was quantified by flow cytometry as a second indicator of apoptosis. Approximately $20 \%$ of cells isolated from mammary glands of $\mathrm{ACI}$ and $\mathrm{BN}$ rats that were treated with $\mathrm{E} 2$ for 3 weeks stained positive for Annexin $\mathrm{V}$ and negative for PI (Figure 3C and 3D). When an involuting mammary gland from an ACI rat (3 days post-lactation) was evaluated as a positive control, approximately $80 \%$ of cells isolated cells stained positive for Annexin V. Together, these data suggest that the levels of apoptosis in the mammary glands of $\mathrm{E} 2$ treated $\mathrm{ACI}$ and $\mathrm{BN}$ rats did not differ significantly.
IHC was performed using an antibody to milk proteins to evaluate mammary gland differentiation and to define the nature of the luminal ectasia observed in E2 treated $\mathrm{BN}$ rats (Figure 4). Immunoreactive milk proteins were detected in the lumens of sham treated $\mathrm{ACI}$ and $\mathrm{BN}$ rats and the amount of immunostaining did not differ discernibly between these rat strains. Milk proteins were also detected in the lumens of ACI rats treated with E2 for 1,3 and 12 weeks. The most prominent feature of the mammary glands of $\mathrm{E} 2$ treated $\mathrm{BN}$ rats was the markedly dilated lumens that contain immunoreactive milk proteins. These data, together with data presented above, suggest that the primary response of the ACI mammary gland to E2 is cell proliferation, which leads to dramatic epithelial hyperplasia. By contrast, the primary response of the BN mammary gland to E2 appears to be differentiation to an active secretory epithelium associated with luminal ectasia and modest epithelial hyperplasia.

\section{Rat strain specific effects of $17 \beta$-estradiol on gene expression}

To gain insights into the molecular mechanisms that underlie the observed differences in responsiveness of
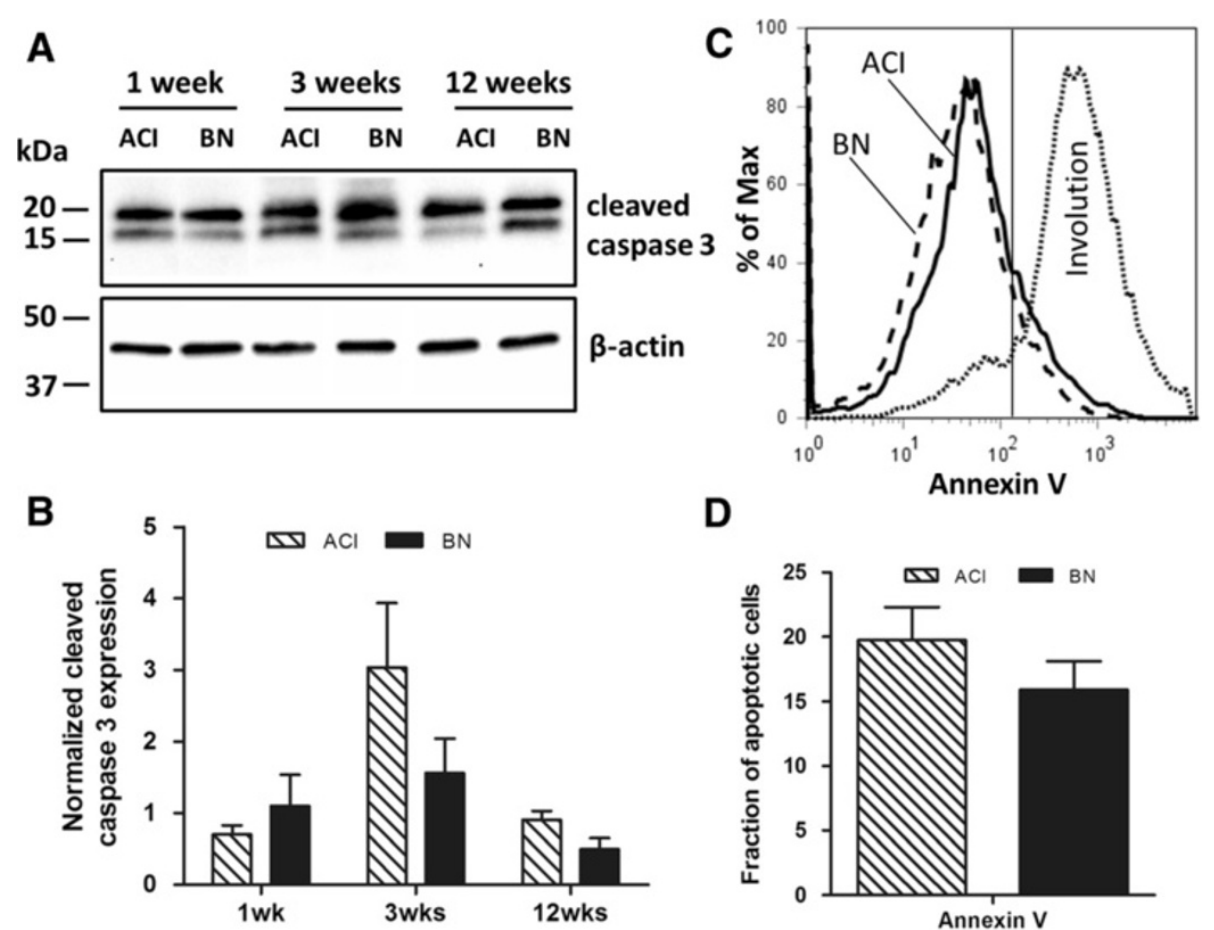

Figure 3 No discernable effect of rat strain on apoptosis in the mammary gland. A, Representative western blots of protein lysates prepared from mammary glands of $\mathrm{ACl}$ and $\mathrm{BN}$ rats, treated with E2 for 1, 3 or 12 weeks, and probed with antibody to cleaved forms (19 kDa and $17 \mathrm{kDa}$ fragments) of caspase $3(n=3)$. B, The amount of cleaved caspase 3 was quantified using a Bio-Rad ChemiDoc XRS + imaging system and normalized to the amount of $\beta$-actin. Each data bar represents the mean $\pm S E M, n=3$ biological replicates. C, Cells isolated from mammary glands of $\mathrm{ACl}$ and $\mathrm{BN}$ rats, treated with E2 for 3 weeks, were stained with Annexin $\mathrm{V}$ and propidium iodide and analyzed by flow cytometry. Cells isolated from an involuting mammary gland (3 days post-lactation) were stained and analyzed as a positive control. D, Each data bar represents the number of apoptotic cells (positive for annexin $\mathrm{V}$, negative for PI) expressed as a percentage of total PI negative cells $($ mean $\pm S E M, n=3)$. 


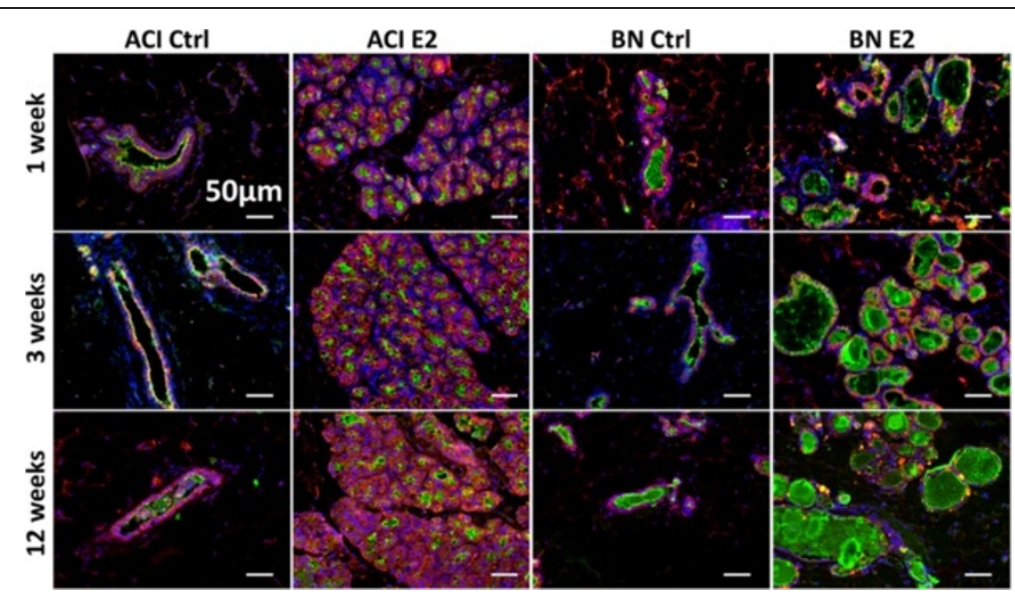

Figure 4 Rat strain-specific effects of $17 \beta$-estradiol on luminal ectasia and expression of milk proteins. Representative fluorescent images of mammary tissues from $\mathrm{ACl}$ and $\mathrm{BN}$ rats, either sham treated $(\mathrm{Ctrl})$ or treated with $\mathrm{E} 2$ for 1,3 or 12 weeks $(n=3)$. Nuclei were identified by staining DNA with DAPI (blue), luminal epithelial cells by immunostaining for K8 (red), and milk proteins were identified by immunostaining using a polyclonal antibody generated against milk specific proteins (green). Note that the mammary glands from E2 treated BN rats exhibit prominent ectatic lumens containing immunoreactive milk protein(s). Scale bars, $50 \mu \mathrm{m}$.

the $\mathrm{ACI}$ and $\mathrm{BN}$ mammary glands to estrogen, gene expression profiles were generated using total RNA isolated from whole mammary glands from $\mathrm{ACI}$ and $\mathrm{BN}$ rats that were treated with E2 for 12 weeks. Transcripts corresponding to 4170 probe sets were observed to be differentially expressed using a false discovery rate of $5 \%$. Of these, transcripts corresponding to 2267 probe sets were more highly expressed in mammary glands from E2 treated ACI rats, relative to matched $\mathrm{BN}$ rats, whereas transcripts corresponding to 1903 probe sets were more highly expressed in mammary glands from BN rats (Additional file 1: Table S2). The genome ontology terms most strongly associated with the differentially expressed transcripts related to immune system process/ response, cell activation/proliferation and cell surface binding/adhesion (Additional file 1: Table S3).

Several genes that encode proteins that serve defined roles in mammary gland development were observed to be more highly expressed in mammary glands of E2 treated ACI rats, including Pgr, Wnt4, Tnfsf11, Areg, Prlr, Stat5a and Gata3. Interestingly, two genes that encode proteins that are secreted into milk and may function in regulation of mammary gland differentiation and milk production, Spp1 and $L c n 2$, were more highly expressed in the mammary glands of $\mathrm{BN}$ rats. Also highly expressed in the mammary glands of $\mathrm{E} 2$ treated $\mathrm{BN}$ rats were multiple genes that encode proteins that regulate the extracellular environment including $M m p 7, M m p$, Mmp11 and Mmp12; Adam8, Adam9, Adam15 and Adam17; and Timp1, Timp2 and Timp3. qRT-PCR was performed for eight differentially expressed genes to validate the microarray data. The data from these analyses verified that Pgr, Wnt4 and Tnfsf11 were expressed at a significantly higher level in the mammary glands of E2 treated ACI rats, whereas Spp1, Lcn2, Mmp7, Mmp9, and Lef1 were expressed at a significantly higher level in the mammary glands of E2 treated $\mathrm{BN}$ rats (Figure 5).

Expression of a subset of the genes that are potentially of functional significance in relation to mammary development, ECM and/or ECM remodeling and mammary cancer susceptibility was further evaluated at the protein level. Although Spp1 was expressed at similar levels in control $\mathrm{ACI}$ and $\mathrm{BN}$ rats, expression increased in response to E2 treatment in mammary glands of BN but not ACI rats, resulting in significantly higher levels of Spp1 in treated $\mathrm{BN}$ rats at the 3 (5.5-fold) and 12 (4.1-fold) week time points, relative to treated ACI rats (Figure 6A and 6D). Lcn2 was virtually undetectable in mammary glands of control and E2 treated ACI rats. By contrast, Lcn2 was highly expressed in mammary glands of control and E2 treated $\mathrm{BN}$ rats (Figure $6 \mathrm{~B}$ and $6 \mathrm{E}$ ). Mmp7 was undetectable in mammary glands of control ACI and BN rats at each of the three time points examined (data not shown), remained undetectable in the mammary glands of $\mathrm{ACI}$ and $\mathrm{BN}$ rats treated with $\mathrm{E} 2$ for 1 week, but was detected in glands from $\mathrm{ACI}$ and $\mathrm{BN}$ rats treated with $\mathrm{E} 2$ for 3 (data not shown) and 12 weeks (Figure 6F and 6I). Moreover, the active $18 \mathrm{kDa}$ form of Mmp7 predominated over the $25 \mathrm{kDa}$ proenzyme in mammary glands from $\mathrm{BN}$ rats treated with E2 for 12 weeks (Figure 6F and 6I). Mmp9 was expressed at similar levels in mammary glands of control and E2 treated ACI and BN rats at the 1 and 3 week time points (data not shown). At the 12 week time point, Mmp9 was expressed at a higher level in E2 treated BN rats, relative to treated ACI rats, and the active form of Mmp9 was observed only in mammary glands from the treated $\mathrm{BN}$ rats (Figure 6G and 6J). 


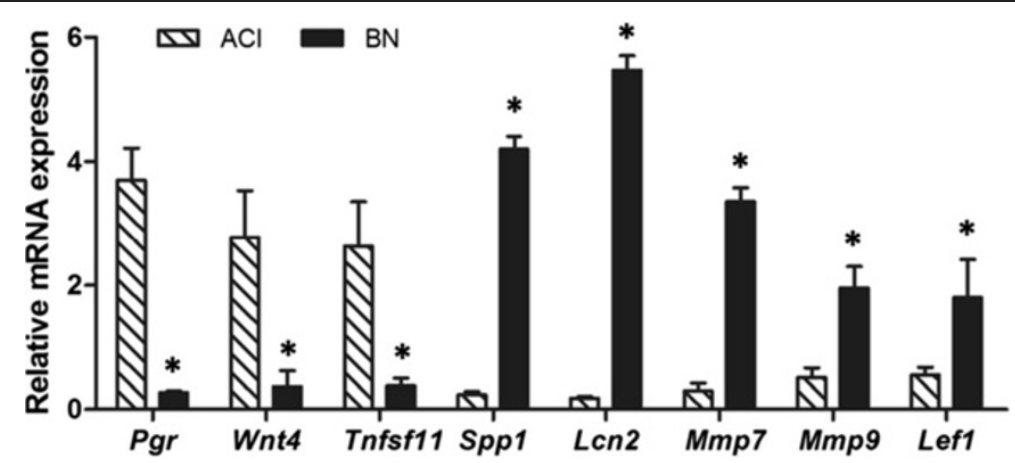

Figure 5 Rat strain-specific effects of $17 \beta$-estradiol on mRNA expression. RNA was isolated from mammary glands of $A C l$ and BN rats, treated with E2 for 12 weeks. Expression of mRNAs encoded by 8 genes of interest was quantified using the $\Delta \Delta C q$ PCR-based method. Each data bar represents the level of the indicated mRNA normalized to the level of $\beta$-actin mRNA (mean $\pm S E M, n=3 .{ }^{*}, p<0.05$ ). The differences observed upon comparison of expression of these $8 \mathrm{mRNA}$ in mammary glands from $\mathrm{E} 2$ treated $\mathrm{ACl}$ and $\mathrm{BN}$ rats were concordant with differences in expression observed upon microarray analysis.

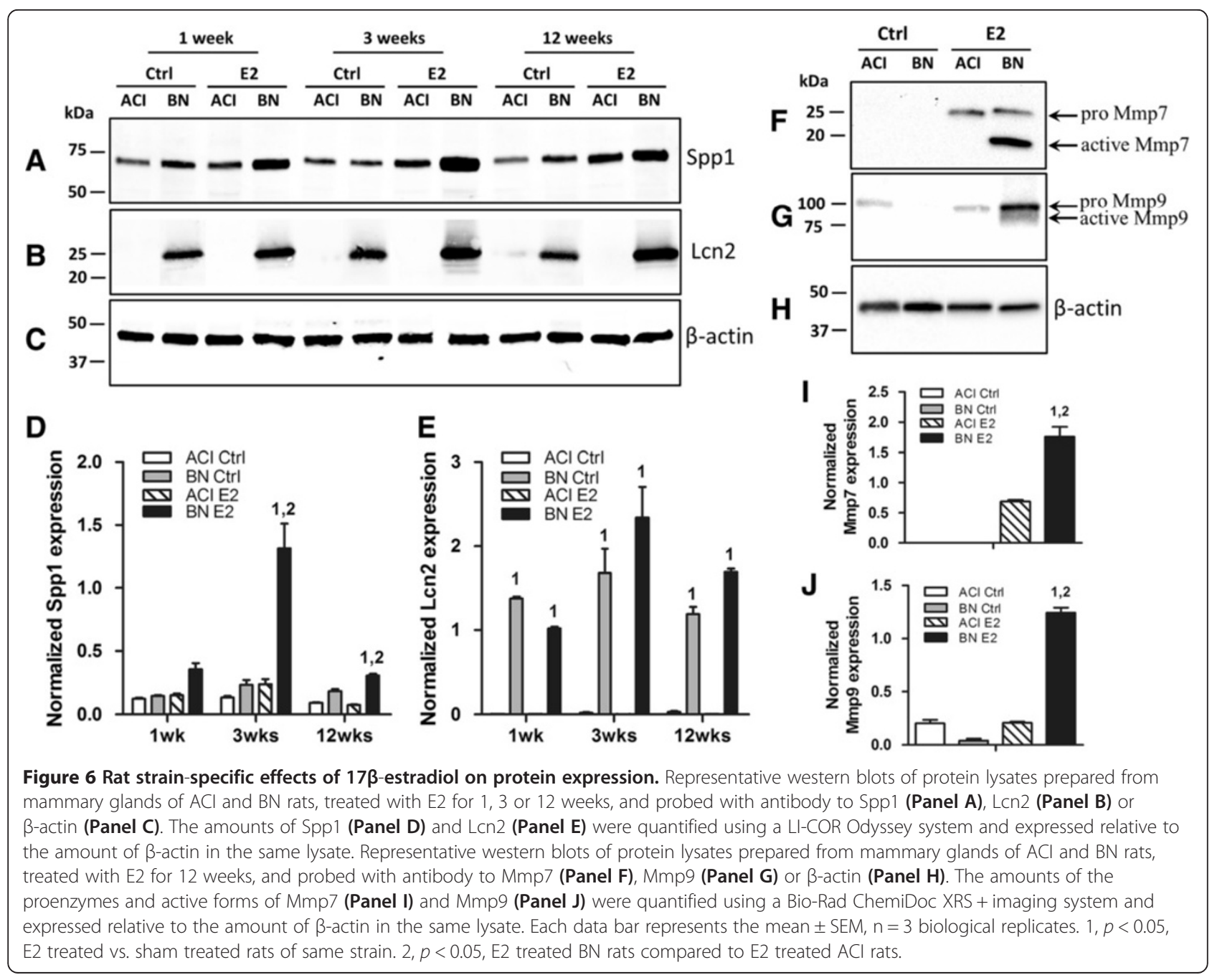




\section{Rat strain specific effects of $17 \beta$-estradiol on extracellular matrix}

Mammary tissues from ACI and BN rats were stained with Picrosirius Red and examined using histopathology and SHG imaging methods to evaluate ECM and associated collagens. When examined using bright field microscopy, all collagen types appear red, while non-collagenous tissues and intraluminal secreta appear green. Under polarized light, the collagen fibers are birefringent in a range of colors from green-yellow-orange-red. When evaluated qualitatively, mammary tissues from sham treated ACI and $\mathrm{BN}$ rats did not differ discernibly with respect to the mammary parenchyma, stroma, ECM or collagen (data not shown). By contrast, the ectatic ducts uniquely present in the mammary glands of $\mathrm{E} 2$ treated $\mathrm{BN}$ rats were generally associated with a robust collagenous stroma (Figure 7A). Evaluation of the ECM using SHG further established the existence of a robust collagenous stroma surrounding ectatic ductal structures in E2 treated BN rats. However, the morphology and content of stromal collagen appeared to be qualitatively and anatomically appropriate to the size of the ducts present (Figure 7B).

\section{Discussion}

Data presented herein demonstrate that the mammary glands of $\mathrm{ACI}$ and $\mathrm{BN}$ rats exhibited marked quantitative and qualitative differences in their cellular and molecular responses to E2. The primary response exhibited by ACI rats, which are uniquely susceptible to mammary cancer when treated with estrogens, was a robust and sustained proliferation within the mammary epithelium. By contrast, the proliferative response of the mammary epithelium of $\mathrm{BN}$ rats, which are highly resistant to estrogen-induced mammary cancer, was restrained and transient. This difference in induction of cell proliferation, not a difference in apoptosis, appeared to be largely responsible for the quantitative differences in epithelial density observed when the mammary glands of ACI and $\mathrm{BN}$ rats were compared following 1, 3 and 12 weeks of E2 treatment. Moreover, the mammary glands of E2 treated BN rats, but not ACI rats, exhibited qualitative phenotypes consistent with differentiation to secretory epithelium, as well as luminal ectasia and associated changes in collagenous stroma. These differences in the responsiveness of the mammary glands of $\mathrm{ACI}$ and $\mathrm{BN}$ rats to $\mathrm{E} 2$ were apparent within one week of initiation of treatment, strongly suggesting that the molecular mechanisms responsible for the rat strain specific responses may be inherent within the mammary glands of these inbred rat strains.

Comparison of gene expression profiles for mammary glands of E2 treated ACI and BN rats revealed differential expression of multiple genes that may have contributed to the differences in luminal epithelial cell proliferation and lobuloalveolar hyperplasia observed upon comparison of these rat strains. Pgr, Wnt4, Tnfsf11 (RankL), Prlr, Stat5a, Areg and Gata3 were expressed at higher levels in mammary glands of E2 treated ACI rats, relative to identically treated BN rats. The protein products encoded by these genes play well defined important roles in mammary gland development. Expression of $\mathrm{Pgr}$ in mammary epithelium is induced by E2 and progesterone, acting through Pgr, plays a requisite role in stimulating lobuloalveolar development during pregnancy [30-32]. Moreover, studies summarized above have demonstrated a requisite role for progesterone in the induction of mammary cancer development by E2 in ACI rats [13,19]. Both Wnt4 and RankL have been demonstrated to function downstream of Pgr in stimulating lobuloalveolar development and have more recently been shown to be requisite paracrine mediators of the actions of progesterone in the regulation of mammary stem cell number [33-37]. Prlr and Stat5a are both required for induction of lobuloalveolar development by prolactin, a second major hormonal regulator of lobulogenesis during pregnancy [38,39]. Areg functions as an important paracrine mediator of the actions of estrogens and ER $\alpha$ on induction of mitogenesis in the mammary epithelium [40,41]. Finally, Gata3 is required for elongation of mammary ducts at puberty and maintenance of differentiated luminal epithelium, and also acts as a positive regulator of expression of Esr1, the gene encoding ER $\alpha[42,43]$. Additional studies are needed to establish whether differential expression of these genes is the cause or the consequence of the observed differences in epithelial cell proliferation and lobuloalveolar hyperplasia exhibited by $\mathrm{E} 2$ treated $\mathrm{ACI}$ and $\mathrm{BN}$ rats.

Other differentially expressed genes encode protein products that are functionally associated with mammary gland differentiation, lactation and/or postlactational involution. Spp1 and Lcn2 are among those genes that were most highly expressed at the mRNA level in mammary glands of $\mathrm{E} 2$ treated $\mathrm{BN}$ rats, relative to identically treated ACI rats. Spp1 encodes a secreted phosphoprotein that is highly expressed in the mammary gland during lactation and involution [44-46]. Spp1 has also been demonstrated to be more highly expressed in mammary glands of parous mice and rats, compared to nulliparous controls $[47,48]$. Inhibition of Spp1 expression in the luminal epithelium of the mouse mammary gland inhibits lobuloalveolar development, expression of genes encoding milk proteins and milk production [49]. Moreover, Spp1 underlies a quantitative trait locus (QTL) in dairy cattle that controls milk yield and protein content [45]. Together, these data suggest that Spp1 regulates multiple processes in the mammary epithelium during pregnancy, lactation and/ or mammary gland involution. Lcn2 encodes a secreted glycoprotein that is highly expressed within the luminal epithelium of the mammary gland during pregnancy 


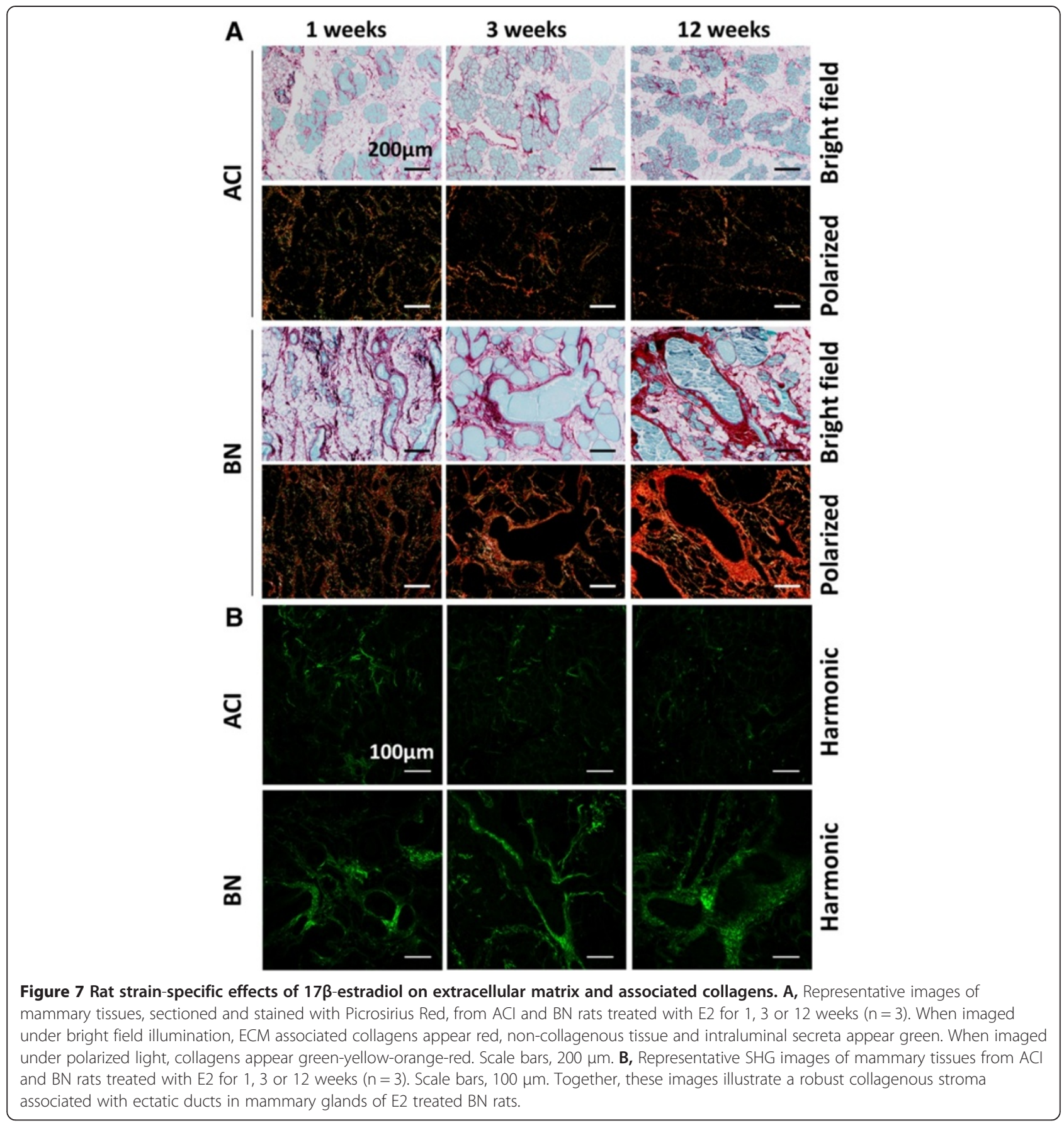

and lactation as well as during mammary gland involution [50,51]. Lcn2 is known to bind a diverse group of ligands, including retinoids, fatty acids, bacterial siderophores and specific MMPs. Suggested functions of Lcn2 in the mammary gland include modulation of inflammation and immunity, ECM remodeling and regulation of iron homeostasis. The functional significance of differential expression of Spp1 and Lcn2 in the mammary glands of $\mathrm{ACI}$ and $\mathrm{BN}$ rats remains under investigation.
As noted above, luminal ectasia and associated collagenous stroma were qualitative phenotypes unique to the mammary glands of E2 treated BN rats. Several genes that encode proteins that are known to modify the extracellular microenvironment were observed to be differentially expressed between E2 treated ACI and BN rats. Two examples are $M m p 7$ and $M m p 9$, both of which were expressed and activated to a greater degree in the mammary glands of $\mathrm{BN}$ rats, relative to $\mathrm{ACI}$ rats. Known functions of these MMPs include ECM remodeling and 
production of active forms of multiple growth factors, cytokines and chemokines [52]. Mmp7 is unique among the MMPs in that its expression in the mammary gland is largely restricted to the glandular epithelium [53]. A role for Mmp7 in mammary gland development is suggested by a study that demonstrated that expression of MMP7 in the mammary epithelium of nulliparous mice under control of the mouse mammary tumor virus (MMTV) promoter induced production of milk proteins, suggesting MMP7 may play a role in mammary gland differentiation [54]. Other studies support a role of Mmp7 in mammary cancer development and/or progression. For example, expression of an MMTV-MMP7 transgene in the mammary epithelium resulted in development of hyperplastic alveolar nodules in a large fraction of aged multiparous mice and shortened the time to onset of mammary tumors in mice that also expressed an MMTV-Neu transgene [53]. Moreover, single nucleotide polymorphisms in $M M P 7$ have been associated with disease free and/or overall survival in two breast cancer case control studies [55,56]. Mmp9 is expressed by the mammary epithelium, stromal fibroblasts and infiltrating immune/inflammatory cells. The highest levels of Mmp9 expression in the mammary gland occur during pregnancy and involution [57,58]. However, the roles of Mmp9 at these developmental stages are not well defined. Mmp9 contributes to mammary cancer metastasis in mouse models and nucleotide variants within $M M P 9$ have been associated with breast cancer metastasis in humans [59,60]. Interestingly, Mmp9 has been demonstrated to form a binary complex with Lcn2, leading to activation and stabilization of this matrix metalloproteinase [61-64]. These data suggest a potential mechanism for the enhanced activation of Mmp9 observed in the mammary glands of $\mathrm{E} 2$ treated $\mathrm{BN}$ rats.

Comparison of gene expression profiles for mammary glands from E2 treated $\mathrm{ACI}$ and $\mathrm{BN}$ rats also revealed differential expression of many genes that encode proteins that reside on the cell surface and function in cell-cell or cell-ECM interactions. One such gene, Cd44, was observed to be expressed at an approximate 10-fold higher level in $\mathrm{BN}$ rats than in $\mathrm{ACI}$ rats. $\mathrm{Cd} 44$ is expressed by the myoepithelium in developing mammary gland and by luminal epithelium in adult mouse mammary gland and human breast [65]. Cd44 null mice exhibit a lactation defect which appears to result from reduced activation of heparin binding epidermal growth factor (HB-EGF) and downstream signaling through ErbB4 [66]. Cd44 null mice also exhibit delayed ductal outgrowth and small TEBs and these phenotypes were attributed to aberrant interactions between myoepithelium and luminal epithelium [65]. Multiple studies have demonstrated a physical interaction between CD44 and Spp1 in a wide variety of cell types, including breast cancer cells, which alters an array of cellular phenotypes including motility and invasiveness
[67-70]. CD44 has also been demonstrated to interact physically and functionally with Mmp7 and Mmp9 in multiple cell types, and by doing so enhances the activities of Mmp7 and Mmp9 on specific substrates within the extracellular environment [66,71-73]. Interestingly, the interaction between CD44 and Mmp9 in PC3 prostate cancer cells has been demonstrated to be induced by Spp1 [74]. CD24 and CD52 were observed to be expressed at higher levels in mammary glands from E2 treated ACI rats, relative to $\mathrm{BN}$ rats. $\mathrm{CD} 24$ encodes a cell surface glycoprotein that has emerged as a marker for mammary stem cells $[75,76]$. In the mouse mammary gland, $\mathrm{Cd} 24$ is expressed in the luminal epithelium and to a lesser extent in the basal epithelium [77,78]. Mice that are homozygous for a $C d 24$ null allele exhibit accelerated ductal elongation and increased branching morphogenesis in the mammary gland [78]. CD52, which is paralagous to $C D 24$, is expressed by lymphocytes and other types of immune cells. Virtually nothing is known regarding the role of CD52 in mammary gland development or function. Ongoing studies are focused on identifying and quantifying the cell types in the mammary glands of $\mathrm{ACI}$ and $\mathrm{BN}$ rats that express these different proteins.

We hypothesize that variation in a subset of the cellular and molecular phenotypes described herein is heritable and underlies the differing susceptibilities of the ACI and $\mathrm{BN}$ rats to E2-induced mammary cancer. We are currently testing this hypothesis by evaluating these phenotypes in a panel of unique congenic rat strains that were developed to characterize the QTL that were identified as genetic determinants of susceptibility to E2induced mammary cancer in intercrosses between susceptible $\mathrm{ACI}$ and resistant $\mathrm{BN}$ rats [22,23]. Our working model is that genetic variants within the Emca QTL impact expression of genes that function downstream of E2 and progesterone to control proliferation, survival and/or differentiation within the mammary epithelium and/or the cellular composition of the stroma and thereby influence susceptibility to E2-induced mammary cancer. Supporting this model is a recently published study in which it was demonstrated that congenic rats that harbor, on the ACI genetic background, BN alleles across the Emca 8 locus on rat chromosome 5 exhibited significantly reduced susceptibility to E2-induced mammary cancer that was accompanied by reduced expression in the mammary gland of Pgr, Wnt4 and Cd52 and increased expression of Spp1, relative to E2 treated ACI rats [24]. We further hypothesize that variation in the different cellular and molecular phenotypes observed in E2 treated $\mathrm{ACI}$ and $\mathrm{BN}$ rats is representative of variation that would exist within the genetically heterogeneous human population. For example, the difference in mammary epithelial density exhibited by E2 treated ACI and $\mathrm{BN}$ rat may be analogous to variation in breast 
mammographic density in humans, which is known to be modified by estrogens as well as other hormonal, genetic and environmental factors and has been strongly associated with breast cancer risk. Additional studies are required to establish cause and effect relationships between the cellular, molecular and mammary cancer susceptibility phenotypes in the rat and to translate the knowledge gained to humans.

\section{Conclusions}

The mammary glands of susceptible ACI and resistant BN rats exhibited marked quantitative and qualitative differences in their cellular and molecular responses to E2.

The luminal epithelium of ACI rats exhibited a rapid and sustained proliferative response to E2, resulting in lobuloalveolar hyperplasia and increased epithelial density. By contrast, the epithelium of BN rats exhibited responses indicative of differentiation to secretory epithelium, as well as luminal ectasia and associated changes in the ECM. Comparison of gene expression profiles for mammary glands of E2 treated $\mathrm{ACI}$ and $\mathrm{BN}$ rats revealed differences in expression of multiple genes whose protein products are required for normal mammary gland development, differentiation and milk production, regulation of the extracellular environment, and cell-cell or cell-ECM interactions. Ongoing studies are focused on defining the relationships between these cellular and molecular phenotypes and the genetically determined differences in susceptibility of $\mathrm{ACI}$ and $\mathrm{BN}$ rats to E2-induced mammary cancer.

\section{Additional files}

Additional file 1: Table S1. Primary and secondary antibodies for immunohistochemistry and western blot; Table S2: Rat strain specific effects of $17 \beta$-Estradiol on gene expression; Table S3: Gene ontology analysis with the differentially expressed transcripts.

Additional file 2: Figure S1. Rat strain-specific effects of $17 \beta$-estradiol on mammary epithelial cell proliferation.

\begin{abstract}
Abbreviations
ACl: August x Copenhagen, Irish; COP: Copenhagen; BN: Brown Norway; E2: 17ß-estradiol; ERa: Estrogen receptor-a; Pgr: Progesterone receptor; Emca: Estrogen-induced mammary cancer; QTL: Quantitative trait loci; GWAS: Genome wide association studies; ECM: Extracellular matrix; PBS: Phosphate buffered saline; DAPI: 4',6-diamidino-2-phenylindole; BrdU: 5-bromo-2'-deoxyuridine; H\&E: Hematoxylin and eosin; K5: Cytokeratin 5; K8: Cytokeratin 8; DMEM: Dulbecco's modified Eagle's medium; PI: Propidium iodide; qRT-PCR: Quantitative real-time PCR; IHC: Immunohistochemistry; SHG: Second Harmonic Generation.
\end{abstract}

\section{Competing interests}

The authors declare that they have no competing interests.

\section{Authors' contributions}

Conception and design, LD, JDS; development of methodology, LD, JDS; acquisition of data, LD, YZ, CLW, RS, KWE, JDS; analysis and interpretation of data, LD, YZ, CLW, RS, KWE, JDS; writing of the manuscript: LD, RS, JDS; study supervision: JDS. All authors read and approved the final manuscript.

\section{Acknowledgments}

This work was supported by National Institutes of Health (R01-CA77876), the Susan Komen Breast Cancer Foundation (KG081343) and the Department of Defense Breast Cancer Research Program (W81XWH-11-1-0175). Shared research resources in the University of Wisconsin Carbone Cancer Center were supported by the Cancer Center Support Grant P30-CA014520. The authors thank Drs. Caroline Alexander and Wei Huang for their valuable input on specific aspects of this research; Dr. Beverly S. Schaffer for assistance in generating gene expression data; the staff in the McArdle Laboratory Animal Facility for providing outstanding care of the research animals; and the staff of the Translational Sciences Biocore, Experimental Pathology, and Flow Cytometry Shared Resource Laboratories in the UW Carbone Cancer Center for their expertise and contributions to this study. Finally, the authors thank all the members of the Shull laboratory for their varied and significant contributions to this work.

\section{Author details}

${ }^{1}$ McArdle Laboratory for Cancer Research, Department of Oncology, School of Medicine and Public Health, University of Wisconsin Madison, 1400 University Avenue, Madison, WI 53706, USA. ${ }^{2}$ UW Carbone Cancer Center, University of Wisconsin Madison, School of Medicine and Public Health, University of Wisconsin Madison, 600 Highland Avenue, Madison, WI 53792, USA. ${ }^{3}$ Molecular and Environmental Toxicology Center, School of Medicine and Public Health, University of Wisconsin Madison, 1300 University Avenue, Madison, WI 53706, USA. ${ }^{4}$ Research Animal Resources Center, Graduate School, University of Wisconsin Madison, 1710 University Avenue, Madison, WI 53726, USA. ${ }^{5}$ Laboratory for Optical and Computational Instrumentation, Graduate School, University of Wisconsin Madison, 1675 Observatory Dr, Madison, WI 53706, USA.

Received: 9 September 2013 Accepted: 26 November 2013 Published: 5 December 2013

\section{References}

1. Carey LA, Perou CM, Livasy CA, Dressler LG, Cowan D, Conway K, Karaca G, Troester MA, Tse CK, Edmiston S, et al: Race, breast cancer subtypes, and survival in the Carolina Breast Cancer Study. JAMA 2006, 295(21):2492-2502.

2. Perou CM, Sorlie T, Eisen MB, van de Rijn M, Jeffrey SS, Rees CA, Pollack JR, Ross DT, Johnsen H, Akslen LA, et al: Molecular portraits of human breast tumours. Nature 2000, 406(6797):747-752.

3. Sattin RW, Rubin GL, Webster LA, Huezo CM, Wingo PA, Ory HW, Layde PM: Family history and the risk of breast cancer. JAMA 1985, 253(13):1908-1913.

4. Slattery ML, Kerber RA: A comprehensive evaluation of family history and breast cancer risk. The Utah Population Database. JAMA 1993, 270(13):1563-1568

5. Bernstein L, Ross RK: Endogenous hormones and breast cancer risk. Epidemiol Rev 1993, 15(1):48-65.

6. Byrne C, Schairer C, Wolfe J, Parekh N, Salane M, Brinton LA, Hoover R, Haile R: Mammographic features and breast cancer risk: effects with time, age, and menopause status. J Natl Cancer Inst 1995, 87(21):1622-1629.

7. Ross RK, Paganini-Hill A, Wan PC, Pike MC: Effect of hormone replacement therapy on breast cancer risk: estrogen versus estrogen plus progestin. J Natl Cancer Inst 2000, 92(4):328-332.

8. Vogel VG, Costantino JP, Wickerham DL, Cronin WM, Wolmark N: The study of tamoxifen and raloxifene: preliminary enrollment data from a randomized breast cancer risk reduction trial. Clin Breast Cancer 2002, 3(2):153-159.

9. Chlebowski RT, Hendrix SL, Langer RD, Stefanick ML, Gass M, Lane D, Rodabough RJ, Gilligan MA, Cyr MG, Thomson CA, et al: Influence of estrogen plus progestin on breast cancer and mammography in healthy postmenopausal women: the Women's Health Initiative Randomized Trial. JAMA 2003, 289(24):3243-3253.

10. Pharoah PD, Antoniou AC, Easton DF, Ponder BA: Polygenes, risk prediction, and targeted prevention of breast cancer. N Engl J Med 2008, 358(26):2796-2803. 
11. Mavaddat N, Antoniou AC, Easton DF, Garcia-Closas M: Genetic susceptibility to breast cancer. Mol Oncol 2010, 4(3):174-191.

12. Easton DF, Pooley KA, Dunning AM, Pharoah PD, Thompson D, Ballinger DG, Struewing JP, Morrison J, Field H, Luben R, et al: Genome-wide association study identifies novel breast cancer susceptibility loci. Nature 2007, 447(7148):1087-1093.

13. Shull JD, Spady TJ, Snyder MC, Johansson SL, Pennington KL: Ovary-intact, but not ovariectomized female $\mathrm{ACl}$ rats treated with 17 beta-estradiol rapidly develop mammary carcinoma. Carcinogenesis 1997, 18(8):1595-1601.

14. Harvell DM, Strecker TE, Tochacek M, Xie B, Pennington KL, McComb RD, Roy SK, Shull JD: Rat strain-specific actions of 17beta-estradiol in the mammary gland: correlation between estrogen-induced lobuloalveolar hyperplasia and susceptibility to estrogen-induced mammary cancers. Proc Natl Acad Sci USA 2000, 97(6):2779-2784.

15. Adamovic T, Roshani L, Chen L, Schaffer BS, Helou K, Levan G, Olsson B, Shull JD: Nonrandom pattern of chromosome aberrations in 17betaestradiol-induced rat mammary tumors: indications of distinct pathways for tumor development. Genes Chromosomes Cancer 2007, 46(5):459-469.

16. Ruhlen RL, Willbrand DM, Besch-Williford CL, Ma L, Shull JD, Sauter ER: Tamoxifen induces regression of estradiol-induced mammary cancer in the ACI.COP-Ept2 rat model. Breast Cancer Res Treat 2009, 117(3):517-524.

17. Li SA, Weroha SJ, Tawfik O, Li JJ: Prevention of solely estrogen-induced mammary tumors in female aci rats by tamoxifen: evidence for estrogen receptor mediation. J Endocrino/ 2002, 175(2):297-305.

18. Singh B, Bhat NK, Bhat HK: Partial inhibition of estrogen-induced mammary carcinogenesis in rats by tamoxifen: balance between oxidant stress and estrogen responsiveness. PLoS One 2011, 6(9):e25125.

19. Blank EW, Wong PY, Lakshmanaswamy R, Guzman R, Nandi S: Both ovarian hormones estrogen and progesterone are necessary for hormonal mammary carcinogenesis in ovariectomized ACI rats. Proc Natl Acad Sci USA 2008, 105(9):3527-3532.

20. Spady TJ, Harvell DM, Snyder MC, Pennington KL, McComb RD, Shull JD: Estrogen-induced tumorigenesis in the Copenhagen rat: disparate susceptibilities to development of prolactin-producing pituitary tumors and mammary carcinomas. Cancer Lett 1998, 124(1):95-103.

21. Gould KA, Tochacek M, Schaffer BS, Reindl TM, Murrin CR, Lachel CM, VanderWoude EA, Pennington KL, Flood LA, Bynote KK, et al: Genetic determination of susceptibility to estrogen-induced mammary cancer in the $\mathrm{ACl}$ rat: mapping of Emca1 and Emca2 to chromosomes 5 and 18. Genetics 2004, 168(4):2113-2125.

22. Schaffer BS, Lachel CM, Pennington KL, Murrin CR, Strecker TE, Tochacek M Gould KA, Meza JL, McComb RD, Shull JD: Genetic bases of estrogeninduced tumorigenesis in the rat: mapping of loci controlling susceptibility to mammary cancer in a Brown Norway $\mathrm{x} \mathrm{ACl}$ intercross. Cancer Res 2006, 66(15):7793-7800.

23. Shull JD: The rat oncogenome: comparative genetics and genomics of rat models of mammary carcinogenesis. Breast Dis 2007, 28:69-86.

24. Schaffer BS, Leland-Wavrin KM, Kurz SG, Colletti JA, Seiler NL, Warren CL, Shull JD: Mapping of Three Genetic Determinants of Susceptibility to Estrogen-Induced Mammary Cancer within the Emca8 Locus on Rat Chromosome 5. Cancer Prev Res (Phila) 2013, 6(1):59-69.

25. Harvell DM, Strecker TE, Xie B, Pennington KL, McComb RD, Shull JD: Dietary energy restriction inhibits estrogen-induced mammary, but not pituitary, tumorigenesis in the ACl rat. Carcinogenesis 2002, 23(1):161-169.

26. Delp CR, Treves JS, Banerjee MR: Neoplastic transformation and DNA damage of mouse mammary epithelial cells by $\mathrm{N}$-methyl-N'-nitrosourea in organ culture. Cancer Lett 1990, 55(1):31-37.

27. Vermes I, Haanen C, Steffens-Nakken H, Reutelingsperger C: A novel assay for apoptosis. Flow cytometric detection of phosphatidylserine expression on early apoptotic cells using fluorescein labelled Annexin V. $\mathrm{J}$ Immunol Methods 1995, 184(1):39-51.

28. Provenzano PP, Eliceiri KW, Campbell JM, Inman DR, White JG, Keely PJ: Collagen reorganization at the tumor-stromal interface facilitates local invasion. BMC Med 2006, 4(1):38.

29. Provenzano PP, Eliceiri KW, Yan L, Ada-Nguema A, Conklin MW, Inman DR, Keely PJ: Nonlinear optical imaging of cellular processes in breast cancer. Microsc Microanal 2008, 14(6):532-548

30. Humphreys RC, Lydon JP, O'Malley BW, Rosen JM: Use of PRKO mice to study the role of progesterone in mammary gland development. J Mammary Gland Biol Neoplasia 1997, 2(4):343-354.
31. Brisken C, Park S, Vass T, Lydon JP, O'Malley BW, Weinberg RA: A paracrine role for the epithelial progesterone receptor in mammary gland development. Proc Natl Acad Sci USA 1998, 95(9):5076-5081.

32. Conneely $\mathrm{OM}$, Jericevic BM, Lydon JP: Progesterone receptors in mammary gland development and tumorigenesis. J Mammary Gland Biol Neoplasia 2003, 8(2):205-214.

33. Brisken C, Heineman A, Chavarria T, Elenbaas B, Tan J, Dey SK, McMahon JA, McMahon AP, Weinberg RA: Essential function of Wnt-4 in mammary gland development downstream of progesterone signaling. Genes Dev 2000, 14(6):650-654.

34. Fernandez-Valdivia R, Mukherjee A, Ying Y, Li J, Paquet M, DeMayo FJ, Lydon JP: The RANKL signaling axis is sufficient to elicit ductal side-branching and alveologenesis in the mammary gland of the virgin mouse. Dev Biol 2009, 328(1):127-139.

35. Gonzalez-Suarez E, Branstetter D, Armstrong A, Dinh H, Blumberg H, Dougall WC: RANK overexpression in transgenic mice with mouse mammary tumor virus promoter-controlled RANK increases proliferation and impairs alveolar differentiation in the mammary epithelia and disrupts lumen formation in cultured epithelial acini. Mol Cell Biol 2007, 27(4):1442-1454

36. Joshi PA, Jackson HW, Beristain AG, Di Grappa MA, Mote PA, Clarke CL, Stingl J, Waterhouse PD, Khokha R: Progesterone induces adult mammary stem cell expansion. Nature 2010, 465(7299):803-807.

37. Asselin-Labat ML, Vaillant F, Sheridan JM, Pal B, Wu D, Simpson ER, Yasuda H, Smyth GK, Martin TJ, Lindeman GJ, et al: Control of mammary stem cell function by steroid hormone signalling. Nature 2010, 465(7299):798-802

38. Liu X, Robinson GW, Wagner KU, Garrett L, Wynshaw-Boris A, Hennighausen $\mathrm{L}$ : Stat5a is mandatory for adult mammary gland development and lactogenesis. Genes Dev 1997, 11(2):179-186.

39. Brisken C, Kaur S, Chavarria TE, Binart N, Sutherland RL, Weinberg RA, Kelly PA, Ormandy CJ: Prolactin controls mammary gland development via direct and indirect mechanisms. Dev Biol 1999, 210(1):96-106.

40. Sternlicht MD, Sunnarborg SW, Kouros-Mehr H, Yu Y, Lee DC, Werb Z: Mammary ductal morphogenesis requires paracrine activation of stromal EGFR via ADAM17-dependent shedding of epithelial amphiregulin. Development 2005, 132(17):3923-3933.

41. Ciarloni L, Mallepell S, Brisken C: Amphiregulin is an essential mediator of estrogen receptor alpha function in mammary gland development. Proc Natl Acad Sci USA 2007, 104(13):5455-5460.

42. Kouros-Mehr H, Slorach EM, Sternlicht MD, Werb Z: GATA-3 maintains the differentiation of the luminal cell fate in the mammary gland. Cell 2006, 127(5):1041-1055.

43. Eeckhoute J, Keeton EK, Lupien M, Krum SA, Carroll JS, Brown M: Positive cross-regulatory loop ties GATA-3 to estrogen receptor alpha expression in breast cancer. Cancer Res 2007, 67(13):6477-6483.

44. Nagatomo T, Ohga S, Takada H, Nomura A, Hikino S, Imura M, Ohshima K, Hara T: Microarray analysis of human milk cells: persistent high expression of osteopontin during the lactation period. Clin Exp Immunol 2004, 138(1):47-53.

45. Sheehy PA, Riley LG, Raadsma HW, Williamson P, Wynn PC: A functional genomics approach to evaluate candidate genes located in a QTL interval for milk production traits on BTA6. Anim Genet 2009, 40(4):492-498.

46. Piantoni $P$, Bionaz M, Graugnard DE, Daniels KM, Everts RE, Rodriguez-Zas SL, Lewin HA, Hurley HL, Akers M, Loor JJ: Functional and gene network analyses of transcriptional signatures characterizing pre-weaned bovine mammary parenchyma or fat pad uncovered novel inter-tissue signaling networks during development. BMC Genomics 2010, 11:331.

47. D'Cruz CM, Moody SE, Master SR, Hartman JL, Keiper EA, Imielinski MB, Cox JD, Wang JY, Ha SI, Keister BA, et al: Persistent parity-induced changes in growth factors, TGF-beta3, and differentiation in the rodent mammary gland. Mol Endocrinol 2002, 16(9):2034-2051.

48. Uehara N, Unami A, Kiyozuka Y, Shikata N, Oishi Y, Tsubura A: Parous mammary glands exhibit distinct alterations in gene expression and proliferation responsiveness to carcinogenic stimuli in Lewis rats. Oncol Rep 2006, 15(4):903-911.

49. Nemir M, Bhattacharyya D, Li X, Singh K, Mukherjee AB, Mukherjee BB: Targeted inhibition of osteopontin expression in the mammary gland causes abnormal morphogenesis and lactation deficiency. J Biol Chem 2000, 275(2):969-976. 
50. Seth P, Porter D, Lahti-Domenici J, Geng Y, Richardson A, Polyak K: Cellular and molecular targets of estrogen in normal human breast tissue. Cancer Res 2002, 62(16):4540-4544

51. Ryon J, Bendickson L, Nilsen-Hamilton M: High expression in involuting reproductive tissues of uterocalin/24p3, a lipocalin and acute phase protein. Biochem J 2002, 367(Pt 1):271-277.

52. Kessenbrock K, Plaks V, Werb Z: Matrix metalloproteinases: regulators of the tumor microenvironment. Cell 2010, 141(1):52-67.

53. Rudolph-Owen LA, Chan R, Muller WJ, Matrisian LM: The matrix metalloproteinase matrilysin influences early-stage mammary tumorigenesis. Cancer Res 1998, 58(23):5500-5506.

54. Rudolph-Owen LA, Cannon P, Matrisian LM: Overexpression of the matrix metalloproteinase matrilysin results in premature mammary gland differentiation and male infertility. Mol Biol Cell 1998, 9(2):421-435.

55. Beeghly-Fadiel A, Shu XO, Long J, Li C, Cai Q, Cai H, Gao YT, Zheng W: Genetic polymorphisms in the MMP-7 gene and breast cancer survival. Int J Cancer 2009, 124(1):208-214

56. Beeghly-Fadiel A, Zheng W, Lu W, Long J, Zheng Y, Cai H, Gu K, Chen Z, Cai Q, Gao YT, et al: Replication study for reported SNP associations with breast cancer survival. J Cancer Res Clin Oncol 2012, 138(6):1019-1026.

57. Sorrell DA, Szymanowska M, Boutinaud M, Robinson C, Clarkson RW, Stein T, Flint DJ, Kolb AF: Regulation of genes encoding proteolytic enzymes during mammary gland development. J Dairy Res 2005, 72(4):433-441.

58. Barker HE, Chang J, Cox TR, Lang G, Bird D, Nicolau M, Evans HR, Gartland A, Erler JT: LOXL2-mediated matrix remodeling in metastasis and mammary gland involution. Cancer Res 2011, 71(5):1561-1572.

59. Martin MD, Carter KJ, Jean-Philippe SR, Chang M, Mobashery S, Thiolloy S, Lynch CC, Matrisian LM, Fingleton B: Effect of ablation or inhibition of stromal matrix metalloproteinase- 9 on lung metastasis in a breast cancer model is dependent on genetic background. Cancer Res 2008, 68(15):6251-6259.

60. Liu D, Guo H, Li Y, Xu X, Yang K, Bai Y: Association between polymorphisms in the promoter regions of matrix metalloproteinases (MMPs) and risk of cancer metastasis: a meta-analysis. PLoS One 2012, 7(2):e31251.

61. Triebel S, Blaser J, Reinke H, Tschesche H: A 25 kDa alpha 2-microglobulinrelated protein is a component of the $125 \mathrm{kDa}$ form of human gelatinase. FEBS Lett 1992, 314(3):386-388.

62. Kjeldsen $L$, Johnsen $A H$, Sengelov $H$, Borregaard $N$ : Isolation and primary structure of NGAL, a novel protein associated with human neutrophil gelatinase. J Biol Chem 1993, 268(14):10425-10432.

63. Tschesche H, Zolzer V, Triebel S, Bartsch S: The human neutrophil lipocalin supports the allosteric activation of matrix metalloproteinases. Eur $J$ Biochem 2001, 268(7):1918-1928.

64. Yan L, Borregaard N, Kjeldsen L, Moses MA: The high molecular weight urinary matrix metalloproteinase (MMP) activity is a complex of gelatinase B/MMP-9 and neutrophil gelatinase-associated lipocalin (NGAL). Modulation of MMP-9 activity by NGAL. J Biol Chem 2001, 276(40):37258-37265.

65. Louderbough JM, Brown JA, Nagle RB, Schroeder JA: CD44 Promotes Epithelial Mammary Gland Development and Exhibits Altered Localization during Cancer Progression. Genes Cancer 2011, 2(8):771-781.

66. Yu WH, Woessner JF Jr, MCNeish JD, Stamenkovic I: CD44 anchors the assembly of matrilysin/MMP-7 with heparin-binding epidermal growth factor precursor and ErbB4 and regulates female reproductive organ remodeling. Genes Dev 2002, 16(3):307-323.

67. Weber GF, Ashkar S, Glimcher MJ, Cantor H: Receptor-ligand interaction between CD44 and osteopontin (Eta-1). Science 1996, 271(5248):509-512.

68. Khan SA, Cook AC, Kappil M, Gunthert U, Chambers AF, Tuck AB, Denhardt DT: Enhanced cell surface CD44 variant (v6, v9) expression by osteopontin in breast cancer epithelial cells facilitates tumor cell migration: novel post-transcriptional, post-translational regulation. Clin Exp Metastasis 2005, 22(8):663-673.

69. Zohar R, Suzuki N, Suzuki K, Arora P, Glogauer M, McCulloch CA, Sodek J: Intracellular osteopontin is an integral component of the CD44-ERM complex involved in cell migration. J Cell Physiol 2000, 184(1):118-130.

70. Robertson BW, Chellaiah MA: Osteopontin induces beta-catenin signaling through activation of Akt in prostate cancer cells. Exp Cell Res 2010, 316(1):1-11.
71. Yu Q, Stamenkovic I: Localization of matrix metalloproteinase 9 to the cell surface provides a mechanism for CD44-mediated tumor invasion. Genes Dev 1999, 13(1):35-48.

72. Yu Q, Stamenkovic I: Cell surface-localized matrix metalloproteinase-9 proteolytically activates TGF-beta and promotes tumor invasion and angiogenesis. Genes Dev 2000, 14(2):163-176.

73. Lynch CC, Vargo-Gogola T, Martin MD, Fingleton B, Crawford HC, Matrisian LM: Matrix metalloproteinase 7 mediates mammary epithelial cell tumorigenesis through the ErbB4 receptor. Cancer Res 2007, 67(14):6760-6767.

74. Desai B, Ma T, Zhu J, Chellaiah MA: Characterization of the expression of variant and standard CD44 in prostate cancer cells: identification of the possible molecular mechanism of CD44/MMP9 complex formation on the cell surface. J Cell Biochem 2009, 108(1):272-284

75. Shackleton M, Vaillant F, Simpson KJ, Stingl J, Smyth GK, Asselin-Labat ML, Wu L, Lindeman GJ, Visvader JE: Generation of a functional mammary gland from a single stem cell. Nature 2006, 439(7072):84-88.

76. Stingl J, Eirew P, Ricketson I, Shackleton M, Vaillant F, Choi D, Li HI, Eaves CJ: Purification and unique properties of mammary epithelial stem cells. Nature 2006, 439(7079):993-997.

77. Sleeman KE, Kendrick H, Ashworth A, Isacke CM, Smalley MJ: CD24 staining of mouse mammary gland cells defines luminal epithelial, myoepithelial/ basal and non-epithelial cells. Breast Cancer Res 2006, 8(1):R7.

78. Cremers N, Deugnier MA, Sleeman J: Loss of CD24 expression promotes ductal branching in the murine mammary gland. Cell Mol Life Sci 2010, 67(13):2311-2322

doi:10.1186/1471-2407-13-573

Cite this article as: Ding et al:: Association of cellular and molecular responses in the rat mammary gland to $17 \beta$-estradiol with susceptibility to mammary cancer. BMC Cancer 2013 13:573.

\section{Submit your next manuscript to BioMed Central and take full advantage of:}

- Convenient online submission

- Thorough peer review

- No space constraints or color figure charges

- Immediate publication on acceptance

- Inclusion in PubMed, CAS, Scopus and Google Scholar

- Research which is freely available for redistribution

Submit your manuscript at www.biomedcentral.com/submit
C Biomed Central 